\title{
Experimental Heart Failure Induces Alterations of the Lung Proteome - Insight into Molecular Mechanisms
}

\author{
Christoph Birner $^{\mathrm{a}} \quad$ Sarah Hierl $^{\mathrm{a}} \quad$ Alexander Dietl $^{\mathrm{a}} \quad$ Julian Hupf ${ }^{\mathrm{a}}$ \\ Carsten Jungbauer ${ }^{\mathrm{a}}$ Peter M. Schmid ${ }^{\mathrm{a}}$ Petra Rümmele $^{\mathrm{b}}$ Rainer Deutzmann ${ }^{c}$ \\ Günter Riegger ${ }^{a} \quad$ Andreas Luchner ${ }^{a}$
}

aDepartment of Internal Medicine II, University Hospital Regensburg, 'Institute for Pathology, University of Regensburg, 'Department of Biochemistry I, University of Regensburg, Regensburg, Germany

\author{
Key Words \\ Experimental heart failure $\cdot$ Proteomics $\bullet$ Lung
}

\begin{abstract}
Background: Heart failure (CHF) is characterized by dyspnea and pulmonary changes. The underlying molecular adaptations are unclear, but might provide targets for therapeutic interventions. We therefore conceived a study to determine molecular changes of early pulmonary stress failure in a model of tachycardia-induced heart failure. Methods: $\mathrm{CHF}$ was induced in rabbits by progessive right ventricular pacing $(n=6)$. Invasive blood pressure measurements and echocardiography were repeatedly performed. Untreated animals served as controls $(n=6)$. Pulmonary tissue specimens were subjected to twodimensional gel electrophoresis, and differentially expressed proteins were identified by mass spectrometry. Selected proteins were validated by Western Blot analysis and localized by immunohistochemical staining. Results: $\mathrm{CHF}$ animals were characterized by significantly altered functional, morphological, and hemodynamic parameters. Upon proteomic profiling, a total of 33 proteins was found to be differentially expressed in pulmonary tissue of CHF animals (18 up-regulated, and 15 down-regulated) belonging to 4 functional groups: 1 . proteins involved in maintaining cytoarchitectural integrity, 2. plasma proteins indicating impaired alveolar-capillary permeability, 3. proteins with antioxidative properties, and 4 . proteins participating in the metabolism of selenium compounds Conclusion: Experimental heart failure profoundly alters the pulmonary proteome. Our results supplement the current knowledge of pulmonary stress failure by specifying its molecular fundament.
\end{abstract}




\section{Introduction}

Heart failure (CHF) is increasingly seen as complex systemic disorder, which means that the failing heart pathophysiologically interacts with diverse other organs, thereby causing or aggravating organ malfunctions, which in turn further aggravate the poor outcome of such individuals [1]. Thereof, pulmonary dysfunction leading to vascular congestion, interstitial, and alveolar lung edema is of outstanding clinical relevance for both acute and chronic care of heart failure patients [2,3], and hence deserves detailed mechanistic evaluation.

Current evidence shows that pulmonary pressure and volume overload, as it occurs in heart failure, initially results in an impaired anatomical configuration of the alveolarcapillary membrane, which is characterized by endothelial and alveolar cell breaks [4-7]. These ultrastructurally evidenced alterations, usually termed "stress failure", might be reversible as soon as the causing stressors diminish, but will otherwise end in a progressive remodeling process, which is identified by collagen proliferation in the extracellular matrix and a reexpression of fetal genes [8-11]. As in the heart, these later adaptations might initially be protective (by preventing further edema formation), but deleterious in the long term (by exacerbating symptoms and exercise intolerance) [12].

Hitherto characterization of early pulmonary alterations in heart failure is largely confined to structural and ultrastructural examinations, whereas the knowledge of underlying molecular mechanisms is still very scarce, but otherwise important for defining potential new therapeutic targets.

We therefore conceived an unbiased proteomic screening approach to detect molecular pulmonary adaptations in a model of tachycardia-induced heart failure in rabbits. As we could recently show, such a study concept proves to be effective for unveiling pathophysiologically meaningful molecular alterations in heart failure [13].

\section{Materials and Methods}

Animal model

For this study, the model of tachycardia-induced heart failure in rabbits was used due to two main reasons: first, this model reliably mimics neurohumoral, structural, functional, hemodynamic, and electrophysiological adaptations exactly as they occur in human heart failure [13-19], and secondly, rabbits were shown to share important similarities with humans regarding lung anatomy and pathophysiology [20].

A total of 12 male rabbits (chinchilla bastard) was examined for this study. Six animals underwent implantation of a programmable cardiac pacemaker (Medtronic Minix 8340, Minneapolis, MN or Vitatron Model 810, Dieren, NL) with a transvenous right ventricular lead forming the CHF group, and 6 untreated animals served as controls (CTRL group). Experimental heart failure was induced by progressive rapid right ventricular pacing over a total of 30 days as described previously [13-17]. In brief, animals of the CHF group were paced with 330 beats per minute (bpm) for 10 days resulting in early left ventricular dysfunction, then $360 \mathrm{bpm}$ for another 10 days, and finally at $380 \mathrm{bpm}$ during the last 10 days leading to congestive heart failure. All experiments were conducted under the regulation and with permission of the local committee of animal care.

\section{Echocardiography and hemodynamic measurements}

The development of heart failure was documented by transthoracic echocardiography, which was conducted under light sedation (5 mg midazolam i.m.) after halting the pacemaker stimulation at baseline and then at the end of each pacing period, i.e. after 10, 20, and 30 days. Every echocardiographic examination comprised a long and short-axis view (HP Sonos 5500, $12 \mathrm{MHz}$ probe) from the left parasternal window. Left atrial diameter, LV end-diastolic (LVIDd) and end-systolic (LVIDs) dimensions and diastolic and systolic thickness of the left ventricular anteroseptal wall (IVSd and IVSs) and posterior wall (LVPWd and LVPWs) were determined from three repeated 2D guided M-mode tracings using the ASE convention, and fractional shortening (FS) was calculated from these measurements. Conscious arterial pressure and heart rate were determined invasively via the medial ear artery under light sedation and after halting the pacemaker stimulation at baseline and at the end of each pacing period. 


\section{Protein isolation from pulmonary tissue for 2D-PAGE}

After animals were euthanized, thoracotomy was performed, and fractions of pulmonary tissue were excised rapidly. Afterwards, tissue specimens were thoroughly washed in ice-cold saline solution to remove all blood remnants, and homogenized by grinding under liquid nitrogen. Small amounts of tissue homogenates were transferred into $1.5 \mathrm{ml}$ tubes and immediately covered by $1 \mathrm{ml}$ of urea/thiourea lysis buffer ( $2 \mathrm{M}$ thiourea, $7 \mathrm{M}$ urea, $4 \%$ (w/v) CHAPS, $1 \%$ (w/v) DTT, $2 \%$ (v/v) carrier ampholytes (pH 3-10) and $10 \mathrm{mM}$ Pefabloc (proteinase inhibitor). After vortexing and incubating for one hour at room temperature, samples were centrifuged $\left(20800 \mathrm{~g}, 15^{\circ} \mathrm{C}\right)$, and the supernatants were aspirated. Protein quantification of the supernatants was done using a commercial kit (2-D Quant Kit; GE Healthcare, Fairfield, USA) as described by the manufacturer.

\section{Two-dimensional gel electrophoresis}

The 2D-PAGE was performed according to Görg et al. [21, 22] with modifications as described previously [13]. Immobilized pH gradient (IPG) strips (IPG pH 3-10, $18 \mathrm{~cm}$, GE Healthcare) were first actively rehydrated with the sample $(750 \mu \mathrm{g}$ of protein solution in $350 \mu \mathrm{l}$ rehydration buffer [ $8 \mathrm{M}$ urea, $1 \%$ CHAPS, $0.4 \%$ DTT and $0.5 \%$ carrier ampholyte]) at $50 \mathrm{~V}$ with $50 \mu \mathrm{A} /$ strip for $16 \mathrm{hrs}$, followed by a stepwise increase of voltage under constant temperature conditions $\left(20^{\circ} \mathrm{C}\right)$ using an Ettan IPGphor 3 Isoelectric Focusing Unit (GE Healthcare, Fairfield, USA): $500 \mathrm{~V}$ for 2:15 hrs, $1000 \mathrm{~V}$ for 1:30 hrs, rapid voltage ramping to $8000 \mathrm{~V}$ within $1: 00 \mathrm{~h}, 8000 \mathrm{~V}$ for 3:00 hrs, and finally $1000 \mathrm{~V}$ for a maximum of 20:00 hrs until further processing. Equilibration was done by reducing and alkylating the IPG strips for $15 \mathrm{~min}$ each, using $1 \%$ $(\mathrm{w} / \mathrm{v})$ DTT and 4\% (w/v) iodoacetamide in equilibration buffer (6 M urea, 30\% (w/v) glycerol, 2\% (w/v) SDS in $0.05 \mathrm{M}$ Tris-HCl buffer at pH 8.8), respectively. Second dimension electrophoresis was carried out with an Ettan DALTsix Electrophoresis Unit (GE Healthcare, Fairfield, USA) at $25^{\circ} \mathrm{C}$ and at constant voltage of $600 \mathrm{~V}$ at $400 \mathrm{~mA}$ for $16-17 \mathrm{hrs}$ using $26 \times 20 \mathrm{~cm}$ SDS gels with $12.5 \%$ (v/v) acrylamide. To visualize the separated protein spots, gels were stained with colloidal Coomassie Brilliant Blue G250 as described by the manufacturer (Roti-Blue, Carl Roth, Germany). Molecular mass standards over the range $10-170 \mathrm{kDa}$ were obtained from PeqLab Biotec, Erlangen, Germany. For each biological replicate at least three technical replicates were prepared.

\section{Image analysis and quantification}

Gels were scanned and digitized at 300 dpi using an Image Scanner III (GE Healthcare, Fairfield, USA). Spot detection, quantification, and matching were done by applying the MELANIE software (MELANIE version 7.0, GeneBio, Switzerland) after manual adjustment of the smooth, min area, and saliency parameters. Normalization was conducted by defining the intensity of each spot as a proportion of the total intensity from the entire gel. Statistical analysis was automatically done by the software using oneway ANOVA with statistical significance being set at $P$ values less than 0.05 . All gel spots with significant differential expressions between two groups were highlighted and checked manually.

\section{Protein identification by mass spectrometry}

The protein identification procedure has been comprehensively detailed in our previous work [13]. In brief, differentially expressed proteins were cut out from the gels, washed, and digested by trypsin (sequencing grade, Roche). Mass spectrometry was done by MALDI-MS and-MS/MS on a 4800 Proteomics Analyzer running with the v3.5.3 4000 series explorer software (AB Sciex). After dissolving the digests in matrix solution and spotting onto the target plates, MS was performed in positive reflector mode over the $800-4000 \mathrm{~m} / \mathrm{z}$ mass range. On the twelve most intense peaks, MALDI-MS/MS was performed. The raw data were then launched to Mascot using the standard program tool GPS Explorer (v3.6., AB Sciex), and Mascot (v2.1., Matrix Science) was used as search engine to search a local copy of the NCBInr data base. To assign the detected proteins to their putative biological process and molecular function, a comprehensive data search was performed using the Uniprot databases (www.uniprot.org) and Panther software tools (www. pantherdb.org).

\section{Western blot analysis}

For validating expression differences, Western Blot analysis was performed for selected proteins. For this purpose, 10-40 $\mu \mathrm{g}$ of protein were dissolved in $10 \mu \mathrm{l}$ buffer solution (BioRad Laemmli Buffer with 
beta-Mercaptoethanol), incubated at $95{ }^{\circ} \mathrm{C}$ for 5 minutes and then cooled on ice. Protein solutions and molecular weight standards were transfered on precast gels (Mini Protean TGX stainfree any kD, BioRad), and separated at $100-150 \mathrm{~V}$ and $35 \mathrm{~mA}$. After activating the proteins gels with BioRad ChemiDoc MP for 2.5 minutes, proteins were transfered at $2.5 \mathrm{~A}$ and $25 \mathrm{~V}$ for 3-5 minutes using the Trans Blot Turbo System (BioRad). Blots were scanned with ChemiDoc MP System and then washed with TBST twice for 5 minutes each and blocked with 3\% BSA in TBST for 1 hour at room temperature. After washing the blots three times with TBST, primary antibodies were incubated in $1 \%$ BSA in TBST at $4{ }^{\circ} \mathrm{C}$ over night, and blots were washed again three times with TBST. Second antibodies were linked with abcam Dylight (450/650/488 $\mathrm{nm}$ ) fluorescence stain and used in a 1:7000-1:10000 dilution (TTBS/1\%BSA). After $1 \mathrm{~h}$ incubation at room temperature, blots were washed three times with TBST and once with TBS, and were afterwards analyzed using the ChemiDoc MP (BioRad) device.

\section{Immunohistochemical staining}

To localize selected proteins, immunohistochemical stainings were performed. For this purpose, 3$5 \mu \mathrm{m}$ paraffine slices were first rinsed with Xylol (2x 10 minutes) to remove paraffine, then treated with Ethanol (2x minutes 100\%, 2x 5 minutes 96\%, 1x 5 minute 70\%), and afterwards washed with PBS for $2 \times 5$ minutes. Antigen retrieval was done for 10 minutes in a microwave with $0.01 \mathrm{M}$ sodium citrate buffer $\mathrm{pH}$ 6.0.

Endogen Biotin was blocked with Avidin/Biotin Blocking Kit (vector/Linaris SP-2001) followed by blocking of unspecific bindings with Superblock (Pierce). After decanting the Superblock solution, the first antibody (Annexin A2: ab54771, Abcam, UK; Catalase: ab125688, Abcam, UK; Albumin: ab8940, Abcam, UK; Moesin: ab126825, Abcam, UK; $\beta$-Actin: ab8226, Abcam, UK; each 1:100/1:200 diluted with PBS) was incubated on the slices for 2 hours, which were afterwards washed with PBS twice for 5 minutes, respectively. The second antibodies (Dianova preadsorbed) were incubated for 1 hour at room temperature and washed off by rinsing with PBS twice. For development, the ABC AP Kit was used according to the manufacturer's instructions (AK-5000). Slices were afterwards stained with Mayers hematoxylin for 5-10 minutes, incubated with aqua for 30 minutes, rinsed with ethanol $(70 \%, 96 \%, 100 \%)$, and finally covered with DePex (Serva).

\section{Statistical analysis}

Data are expressed as mean \pm SD or mean \pm S.E.M. Differences between two analyzed groups were assessed by the Student's t-test or ANOVA when appropriate. Statistical significance was defined as $\mathrm{P}<0.05$.

\section{Results}

Cardiac adaptations in tachycardia-induced heart failure

Rapid ventricular pacing resulted in profound morphological and functional changes of the heart (Table 1): Both left ventricular end-systolic and end-diastolic diameters were significantly enlarged (LVIDs $1.21 \pm 0.11$ vs. $0.79 \pm 0.11 \mathrm{~cm}$ and LVIDd $1.63 \pm 0.08$ vs. $1.37 \pm 0.12$ $\mathrm{cm} ; \mathrm{P}<0.005$ each). Fractional shortening indicating systolic left ventricular function displayed a marked and significant decline (FS $26.18 \pm 4.53$ vs. $41.40 \pm 3.53 \%$; $<<0.005$ ), and systolic blood pressure decreased accordingly (BP systolic $68.11 \pm 9.37$ vs. $88.40 \pm 17.52 \mathrm{mmHg}$; $\mathrm{P}<0.05)$. Heart rate tended to rise $(247 \pm 23$ vs. $235 \pm 19 \mathrm{mmHg})$, even though this increase did not meet the significance criteria. Importantly, CHF animals developed a significant left $(0.30 \pm 0.08$ vs. $0.14 \pm 0.03 \mathrm{~g} / \mathrm{kg} \mathrm{BW} P=0.001)$ and right atrial $(0.18 \pm 0.03$ vs. $0.10 \pm 0.02 \mathrm{~g} /$ kg BW; $\mathrm{P}=0.001$ ) hypertrophy indicating increased atrial pressures and pulmonary venous congestion.

\section{Alterations of the pulmonary proteome in tachycardia-induced heart failure}

Upon two-dimensional gel electrophoresis of pulmonary tissue, a total of 33 protein spots displayed significant expression differences between control and CHF-animals (Fig. 1 , Tables $2 \mathrm{~A}$ and $2 \mathrm{~B}$ ). Thereof, eighteen spots were up-regulated (Table 2A), and fifteen spots were down-regulated (Table 2B). Remarkably, the secreted plasma proteins albumin and fibrinogen appeared in numerous spatially distinct spots on the $2 \mathrm{D}$ gels indicating 
Table 1. LA, left atrial diameter; LVIDd, left ventricular end-diastolic diameter; LVIDs, left ventricular end-systolic diameter; FS, fractional ute; BP, blood pressure; BW, body weight; LA, left atrial weight; LV, left ventricular weight; RA, right atrial weight; $R V$, right ventricular weight. Mean \pm standard deviation shortening; HR, heart rate; bpm, beats per min-

\begin{tabular}{|c|c|c|c|}
\hline & Control & $\mathrm{CHF}$ & P value \\
\hline \multicolumn{4}{|c|}{ Echocardiographic parameters } \\
\hline $\mathrm{LA}[\mathrm{cm}]$ & $1.18 \pm 0.06$ & $1.60 \pm 0.18$ & 0.0003 \\
\hline LVIDd [cm] & $1.37 \pm 0.12$ & $1.63 \pm 0.08$ & 0.001 \\
\hline LVIDs [cm] & $0.79 \pm 0.11$ & $1.21 \pm 0.11$ & 0.00007 \\
\hline FS [\%] & $42.40 \pm 3.53$ & $26.18 \pm 4.53$ & 0.00004 \\
\hline \multicolumn{4}{|c|}{ Hemodynamic parameters } \\
\hline $\mathrm{HR}[\mathrm{bpm}]$ & $235 \pm 19$ & $247 \pm 23$ & 0.385 \\
\hline BP systolic [mmHg] & $88.40 \pm 17.52$ & $68.11 \pm 9.37$ & 0.036 \\
\hline BP diastolic [mmHg] & $70.40 \pm 14.52$ & $58.99 \pm 11.48$ & 0.178 \\
\hline \multicolumn{4}{|c|}{ Structural parameters } \\
\hline BW [kg] & $4.23 \pm 0.35$ & $3.83 \pm 0.32$ & 0.058 \\
\hline $\mathrm{LA}[\mathrm{g} / \mathrm{kg} \mathrm{BW}]$ & $0.14 \pm 0.03$ & $0.30 \pm 0.08$ & 0.001 \\
\hline $\mathrm{LV}[\mathrm{g} / \mathrm{kg} \mathrm{BW}]$ & $0.66 \pm 0.12$ & $0.66 \pm 0.13$ & 0.980 \\
\hline RA [g/kg BW] & $0.10 \pm 0.02$ & $0.18 \pm 0.03$ & 0.001 \\
\hline $\mathrm{RV}$ [g/kg BW] & $0.35 \pm 0.10$ & $0.40 \pm 0.11$ & 0.411 \\
\hline
\end{tabular}

Fig. 1. Two-dimensional gel. Differentially expressed proteins are numbered as in Tables $2 \mathrm{~A}$ and $2 \mathrm{~B}$.

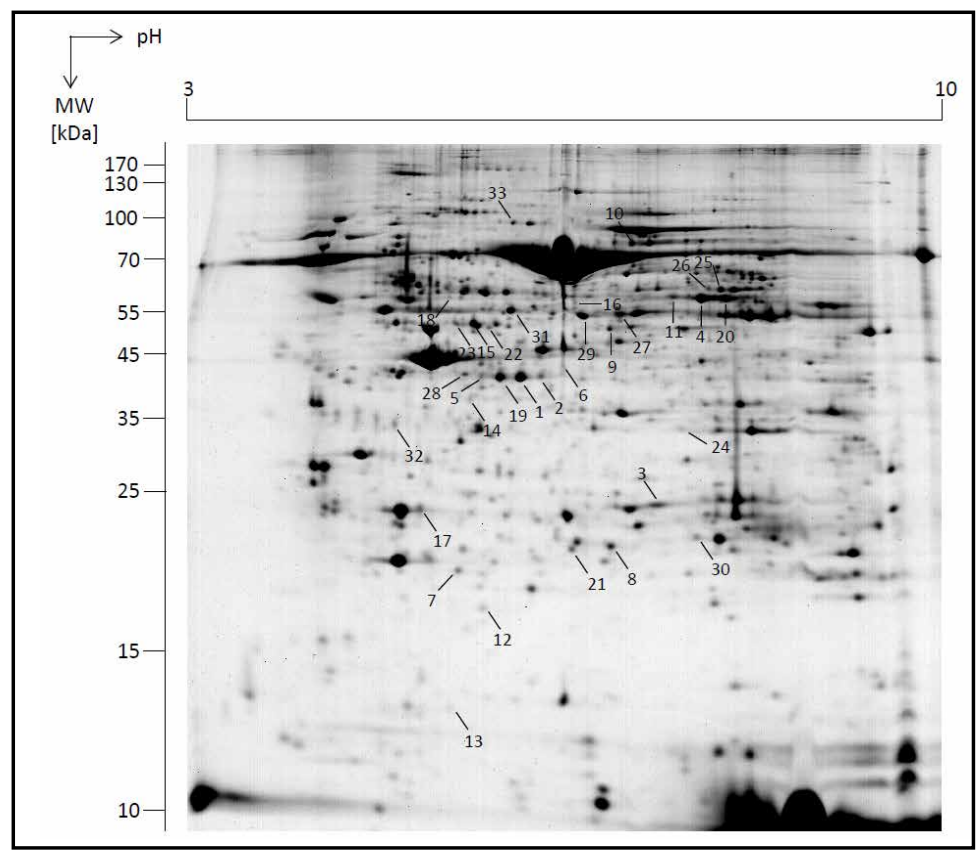

diverse protein modifications, respectively (Fig. 1). By assigning the differentially expressed proteins to their putative molecular function (Fig. 2A), one third of proteins were found to have importance in maintaining structural cellular integrity, one third revealed binding activity, and about $27 \%$ had catalytic activity. As compared to this numerically limited number of molecular function groups, the attribution to the underlying biological processes was more complex (Fig. 2B): Besides lower represented biological processes, about $16 \%$ of proteins were involved in cellular and developmental processes, respectively, $13 \%$ had importance in cellular component organization procedures, and $11 \%$ revealed relevance in cell communication, metabolic, and transport processes, respectively.

By abstracting this functional and procedural grouping, four intrinsically coherent groups could be built: (1) proteins maintaining structural cellular integrity, (2) plasma proteins, (3) proteins involved in antioxidative defense, and (4) proteins metabolizing selenium compounds.

\section{Corroboration of protein expressions by western blot analysis}

Expression differences of two proteins were exemplarily validated by Western Blotting. Catalase (representing the group of proteins with functional enzymatic activity) and moesin (representing the group of proteins involved in cytoskeletal architecture) were both downregulated in lungs of CHF-animals, which was in accordance with the proteomic results (Fig. $3)$. 


\begin{tabular}{|c|c|c|}
\hline Cellular Physiology & Cell Physiol Biochem 2014;33:692-704 & \\
\hline and Biochemistry & $\begin{array}{l}\text { DOI: 10.1159/000358645 } \\
\text { Publisnea onine: tvarcn } 07,2014\end{array}$ & $\begin{array}{l}\text { O } 2014 \text { S. Karger AG, Basel } \\
\text { www.karger.com/cpb }\end{array}$ \\
\hline
\end{tabular}

Table 2. CHF, congestive heart failure; ID, identification number; MW, molecular weight; NCBI, National Center for Biotechnology Information; pI, isoelectric point

\begin{tabular}{|c|c|c|c|c|c|c|c|c|c|}
\hline \multicolumn{10}{|c|}{ 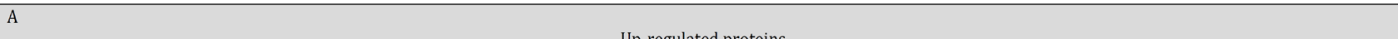 } \\
\hline ID & Identified Protein & $\begin{array}{l}\mathrm{NCBl} \text { account } \\
\text { number }\end{array}$ & $\begin{array}{l}\text { Protein } \\
\text { Score }\end{array}$ & $\begin{array}{c}\text { Experimental } \\
\mathrm{MW} / \mathrm{pI}\end{array}$ & $\begin{array}{l}\text { Up-regulatec } \\
\text { Theoretical } \\
\mathrm{MW} / \mathrm{pl}\end{array}$ & $\begin{array}{l}\text { ed proteins } \\
\text { Sequence } \\
\text { Coverage }\end{array}$ & $\begin{array}{l}\text { Putative } \\
\text { Allocation }\end{array}$ & Putative Biological Function & $\begin{array}{l}\text { Fold Change } \\
\text { (CHF vs. } \\
\text { Control) }\end{array}$ \\
\hline 1 & Serum albumin & gi|126723746 & 303 & $42 / 5.9$ & $69 / 5.9$ & $53 \%$ & Plasma, & Main protein of plasma, regulation of & 2.7 \\
\hline 2 & precursor & & 122 & $42 / 5.9$ & $69 / 5.9$ & $52 \%$ & secreted & the colloidal osmotic pressure of blood, & 2.6 \\
\hline 3 & & & 254 & $24 / 6.2$ & $69 / 5.9$ & $48 \%$ & & major zinc transporter in plasma & 2.5 \\
\hline 4 & & & 240 & $58 / 6.5$ & $69 / 5.9$ & $52 \%$ & & & 2.4 \\
\hline 5 & & & 135 & $42 / 5.5$ & $69 / 5.9$ & $55 \%$ & & & 2.2 \\
\hline 6 & & & 94 & $44 / 5.8$ & $69 / 5.9$ & $59 \%$ & & & 2.1 \\
\hline 7 & & & 124 & $20 / 5.6$ & $69 / 5.9$ & $58 \%$ & & & 2.1 \\
\hline 8 & & & 256 & $22 / 6.0$ & $69 / 5.9$ & $55 \%$ & & & 2.0 \\
\hline 9 & & & 143 & $50 / 6.0$ & $69 / 5.9$ & $57 \%$ & & & 1.9 \\
\hline 10 & & & 120 & $81 / 6.0$ & $69 / 5.9$ & $52 \%$ & & & 1.9 \\
\hline 11 & & & 124 & $63 / 6.2$ & $69 / 5.9$ & $51 \%$ & & & 1.8 \\
\hline 12 & & & 85 & $18 / 5.5$ & $69 / 5.9$ & $56 \%$ & & & 1.6 \\
\hline 13 & & & 89 & $13 / 5.5$ & $69 / 5.9$ & $56 \%$ & & & 1.5 \\
\hline 14 & Beta-actin & gi|335353885 & 247 & $38 / 5.5$ & $29 / 5.2$ & $83 \%$ & Cytoskeleton & $\begin{array}{l}\text { Intracellular protein transport, } \\
\text { exocytosis, endocytosis, mitosis, } \\
\text { cytokinesis, cellular component } \\
\text { morphogenesis }\end{array}$ & 2.0 \\
\hline 15 & $\begin{array}{l}\text { Fibrinogen, gamma } \\
\text { chain }\end{array}$ & gi|291401113 & 76 & $48 / 5.5$ & $50 / 5.7$ & $66 \%$ & Secreted & $\begin{array}{l}\text { Platelet activation and degranulation, } \\
\text { protein polymerization, response to } \\
\text { calcium ion, signal transduction }\end{array}$ & 1.5 \\
\hline 16 & $\begin{array}{l}\text { Selenium binding } \\
\text { protein } 1\end{array}$ & gi|291398005 & 122 & $60 / 5.9$ & $60 / 6.9$ & $67 \%$ & Cytoplasm & $\begin{array}{l}\text { Protein transport; sensing of reactive } \\
\text { xenobiotics in the cytoplasm; involved } \\
\text { in intra-Golgi protein transport }\end{array}$ & 1.5 \\
\hline 17 & $\begin{array}{l}\text { Indolethylamine N- } \\
\text { methyltransferase }\end{array}$ & gi|126723078 & 129 & $24 / 5.5$ & $29 / 5.2$ & $65 \%$ & Cytoplasm & $\begin{array}{l}\text { Metabolic process; important role in } \\
\text { the detoxification of selenium } \\
\text { compounds }\end{array}$ & 1.5 \\
\hline 18 & Tubulin alpha- $1 \mathrm{C}$ chain & gi|6678469 & 129 & $60 / 5.3$ & $50 / 5.0$ & $68 \%$ & Cytoskeleton & Major constituent of microtubules & 1.5 \\
\hline \multicolumn{10}{|l|}{ B } \\
\hline ID & Identified Protein & $\begin{array}{l}\text { NCBI account } \\
\text { number }\end{array}$ & $\begin{array}{l}\text { Protein } \\
\text { Score }\end{array}$ & $\begin{array}{l}\text { Experimental } \\
\mathrm{MW} / \mathrm{pl}\end{array}$ & $\begin{array}{l}\text { Down-regulat } \\
\text { Theoretical } \\
\text { MW/pI }\end{array}$ & $\begin{array}{l}\text { ted proteins } \\
\text { Sequence } \\
\text { Coverage }\end{array}$ & $\begin{array}{l}\text { Putative } \\
\text { Allocation }\end{array}$ & Putative Biological Function & $\begin{array}{l}\text { Fold Change } \\
\text { (CHF vs. } \\
\text { Control) } \\
\end{array}$ \\
\hline 19 & Fibrinogen, beta chain & gi|291401109 & 542 & $42 / 5.8$ & $56 / 8.4$ & $66 \%$ & Secreted & $\begin{array}{l}\text { Platelet activation and degranulation, } \\
\text { protein polymerization, response to }\end{array}$ & -2.4 \\
\hline 20 & & & 361 & $55 / 7.2$ & $56 / 8.4$ & $68 \%$ & & calcium ion, signal transduction & -2.0 \\
\hline 21 & & & 302 & $22 / 6.0$ & $56 / 8.4$ & $69 \%$ & & & -2.0 \\
\hline 22 & $\begin{array}{l}\text { Fibrinogen, gamma } \\
\text { chain }\end{array}$ & gi|291401113 & 352 & $51 / 5.5$ & $50 / 5.7$ & $65 \%$ & Secreted & $\begin{array}{l}\text { Platelet activation and degranulation, } \\
\text { protein polymerization response to }\end{array}$ & -2.0 \\
\hline 23 & & & 122 & $49 / 5.5$ & $50 / 5.7$ & $71 \%$ & & calcium ion, signal transduction & -1.8 \\
\hline 24 & Annexin A2 & gi|291402909 & 185 & $34 / 6.5$ & $46 / 8.3$ & $55 \%$ & $\begin{array}{l}\text { Plasma membrane } \\
\text { / basement } \\
\text { membrane }\end{array}$ & $\begin{array}{l}\text { Intracellular protein transport, } \\
\text { exocytosis, calcium-mediated signaling, } \\
\text { fatty acid metabolic process, cell } \\
\text { motion, calcium-mediated signaling }\end{array}$ & -1.8 \\
\hline 25 & Catalase & gi|291384816 & 587 & $62 / 7.0$ & $60 / 7.0$ & $62 \%$ & Peroxisome & Protects cells from the toxic effects of & -1.6 \\
\hline 26 & & & 294 & $62 / 6.9$ & $60 / 7.0$ & $64 \%$ & & hydrogen peroxide & -1.5 \\
\hline 27 & $\begin{array}{l}\text { Selenium binding } \\
\text { protein } 1\end{array}$ & gi|291398005 & 717 & $55 / 6.0$ & $60 / 6.9$ & $80 \%$ & Cytoplasm & $\begin{array}{l}\text { Protein transport; sensing of reactive } \\
\text { xenobiotics in the cytoplasm; involved } \\
\text { in intra-Golgi protein transport }\end{array}$ & -1.6 \\
\hline 28 & Moesin & gi|291407599 & 493 & $42 / 5.5$ & $92 / 6.5$ & $49 \%$ & Cytoskeleton & $\begin{array}{l}\text { Involved in connections of major } \\
\text { cytoskeletal structures to the plasma } \\
\text { membrane }\end{array}$ & -1.5 \\
\hline 29 & $\begin{array}{l}\text { Mitochondrial } \\
\text { aldehyde } \\
\text { dehydrogenase } 2\end{array}$ & gi|291406975 & 707 & $55 / 6.0$ & $61 / 6.7$ & $77 \%$ & $\begin{array}{l}\text { Mitochondrial } \\
\text { matrix }\end{array}$ & $\begin{array}{l}\text { Electron carrier activity, alcohol } \\
\text { metabolism; ethanol degradation }\end{array}$ & -1.5 \\
\hline 30 & $\begin{array}{l}\text { Biliverdin reductase B } \\
\text { (flavin reductase } \\
\text { (NADPH))-like }\end{array}$ & gi|291414104 & 530 & $22 / 6.3$ & $22 / 6.3$ & $95 \%$ & Cytoplasm & $\begin{array}{l}\text { Biliverdin reductase activity, } \\
\text { nucleotide binding, riboflavin } \\
\text { reductase (NADPH) activity; might } \\
\text { have cytoprotective effects }\end{array}$ & -1.5 \\
\hline 31 & Cytokeratin 8-like & gi|291389225 & 247 & $55 / 5.9$ & $60 / 5.9$ & $64 \%$ & Cytoskeleton & $\begin{array}{l}\text { Belongs to the intermediate filament } \\
\text { family; involved in cytoskeleton } \\
\text { organization }\end{array}$ & -1.3 \\
\hline 32 & $\begin{array}{l}\text { Microfibril-associated } \\
\text { glycoprotein } 4 \\
\text { precursor }\end{array}$ & gi|77627994 & 144 & $34 / 5.1$ & $29 / 5.2$ & $63 \%$ & $\begin{array}{l}\text { Extracellular } \\
\text { matrix, secreted }\end{array}$ & $\begin{array}{l}\text { Involved in calcium-dependent cell } \\
\text { adhesion or intercellular interactions, } \\
\text { extracellular matrix organization }\end{array}$ & -1.3 \\
\hline 33 & Gelsolin isoform 1 & gi|291408438 & 197 & $79 / 5.6$ & $86 / 5.9$ & $57 \%$ & Secreted & $\begin{array}{l}\text { Actin-modulating protein; prevention } \\
\text { of monomer exchange (capping); } \\
\text { promotes assembly of monomers into } \\
\text { filaments }\end{array}$ & -1.3 \\
\hline
\end{tabular}

\section{Cellular localization of selected proteins}

To localize differentially expressed proteins within the pulmonary tissue, immunohistochemical stainings of five proteins (annexin A2, moesin, $\beta$-actin, catalase, and albumin) were performed (Fig. 4). Annexin $A 2$ was generally found in the subepithelial layer (arrows in the left picture) and particularly in the intensely folded basement membranes of bronchial tubes (arrows in the right picture). The cytoskeletal protein moesin displayed extensive accumulation within the interalveolar septa (black arrows in the left and right picture), but was not found in epithelial structures such as the bronchial tubes (white arrow in the left picture). Beta-actin was ubiquitarily detected in interalveolar septa and bronchial 


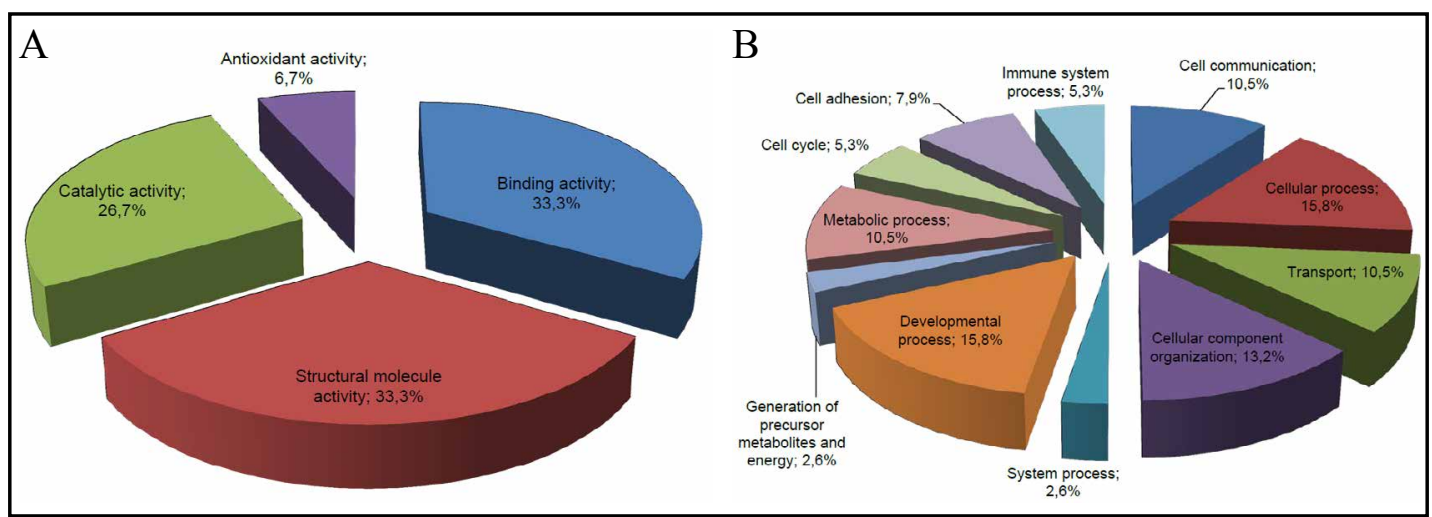

Fig. 2. A: Molecular functions of differentially expressed proteins as composed by use of the Uniprot database (www.uniprot.org) and the Panther software tool (www.pantherdb.org). B: Biological processes covered by the differentially expressed proteins. This analysis was done by use of the Uniprot database (www. uniprot.org) and the Panther software tool (www.pantherdb.org).

Fig. 3. Western blot analysis exemplarily corroborating expression differences of catalase and moesin. White bars, control group; gray bars, CHF group. $* \mathrm{P}<0.05$ vs. control.

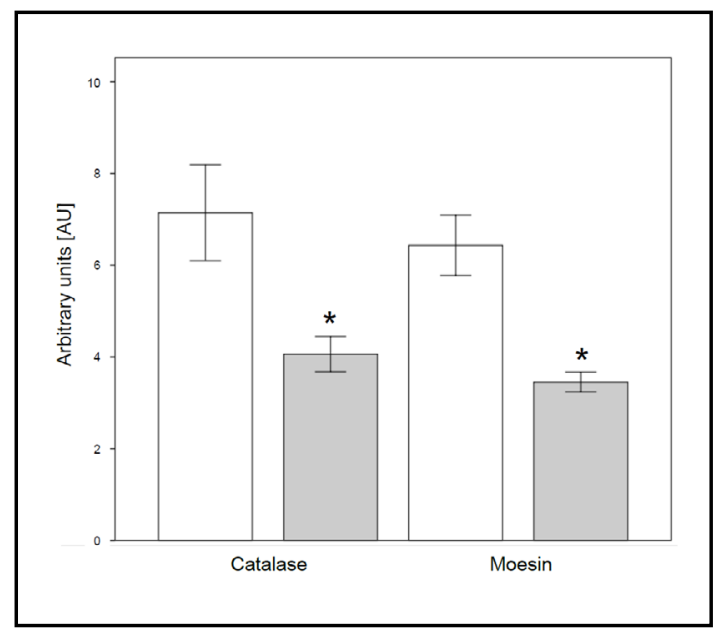

tubes (arrows in the left and right picture) with fine granular alignments within epthelial cells. Catalase, which protects cells from toxic effects of hydrogen peroxide (Table 2B), mainly accumulated in bronchial epithelial cells (arrows in the left picture) and in alveolar macrophages (arrows in the right picture) or alveolar epithelial cells. Finally, the secreted plasma protein albumin has been located in interalveolar septa (arrows in the left picture) and on top of the epithelial layer of bronchial tubes (arrows in the right picture).

\section{Discussion}

The main findings of this study investigating molecular changes of lungs in experimental heart failure are that (1) molecular elements involved in maintaining structure and integrity of pulmonary cells are severly disturbed, (2) enzymes with antioxidative properties are down-regulated, which points to an impaired antioxidative capacity, (3) expression of proteins involved in the metabolism of selenium compounds is changed, and (4) plasma components are detectable in interalveolar septa and on the top of bronchial cells indicating an impaired alveolar-capillary permeability.

These results reflect molecular pulmonary alterations in tachycardia-induced heart failure and thus provide a molecular fundament for pulmonary stress failure. Furthermore, by extending previous proteomic analyses on primary lung pathologies such as lung cancer [23, 24], ARDS [25], asthma [26], sarcoidosis [27] or COPD [28] to pulmonary proteome 
Fig. 4. Immunohistochemical staining for anti-annexin $\mathrm{A} 2$, anti-moesin, anti- $\beta$-actin, anti-catalase, and anti-albumin to detect (sub-) cellular localizations of the proteins. Magnification, x200 and x400. For description refer to the Results section (paragraph "cellular localization of selected proteins").

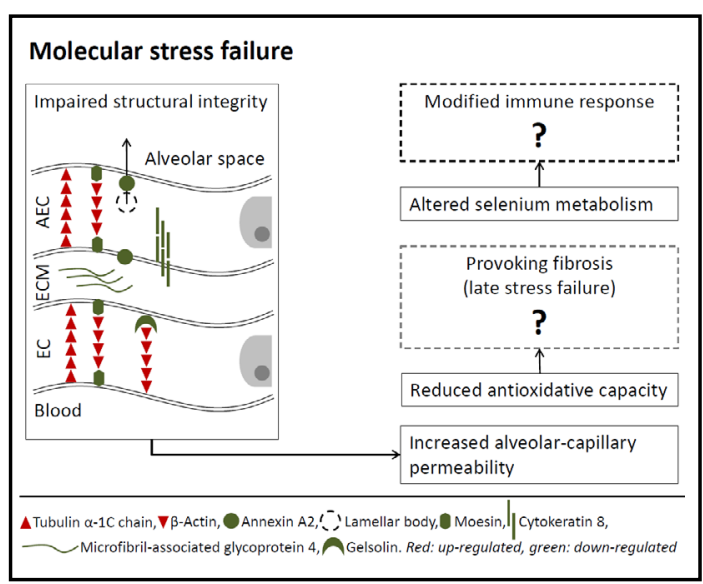

Fig. 5. Integrative concept summarizing the differentially regulated protein classes.

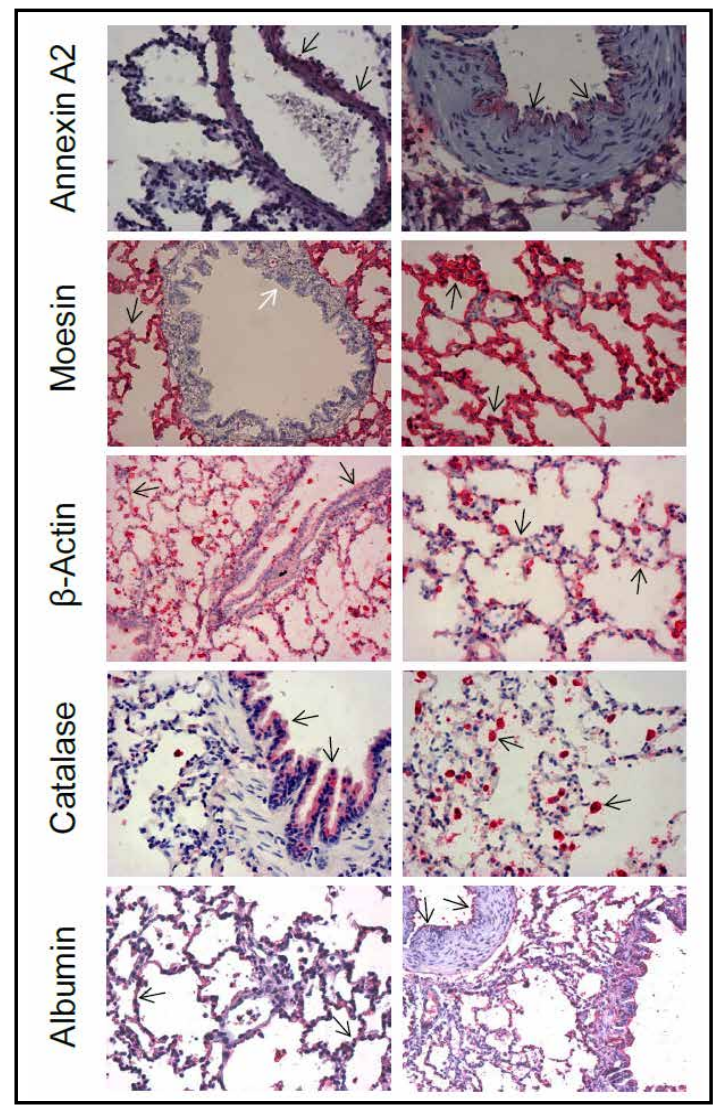

alterations in heart failure, our work additionally demonstrates that proteomics is also suitable to detect secondary lung adaptations.

\section{Previous animal studies investigating pulmonary adaptations in CHF}

Previous studies were mainly performed using dogs [29, 30], guinea pigs [10, 12], mice [31], and rabbits [6] conducting isolated hemodynamic measurements [6] or applying heart failure models of tachypacing $[29,30]$ and aortic banding $[10,12,31]$. These studies revealed an increased endothelial, interstitial and epithelial thickness resulting in a higher pulmonary resistance to high-vascular-pressure injury [29] and a reduced capillary filtration capacity [10], which effectively prevents from further edema formation [12]. Even though these adaptations might be initially protective, ongoing vascular and lung fibrosis, myofibroblast proliferation and leukozyte infiltration, as experimentally evidenced, finally unfolds deleterious effects by causing severe lung disease [31]. Interestingly, these structural lung alterations were seen 49 [29] to 158 days [12] after heart failure was induced, whereas in the short term (i.e., within 4 weeks) lungs primarily revealed functional, but rather less structural adaptations [30]. This early situation was also imitated by artificially exposing rabbit lungs to increasing capillary transmural pressures, which caused disruptions of all layers of the blood-gas barrier resulting in a high-permeability form of lung edema [6] and furthermore hallmarking the so-called alveolar-capillary stress failure $[4,5,7-9,32]$. Which molecular alterations take place in this early period (i.e., within 4 weeks), is largely unknown, but important for determining the molecular basis of the later evolving maladaptations as described above. These molecular changes were analyzed in our study using an unbiased proteomic screening approach.

The molecular basis of structural cellular integrity is disturbed in lungs of CHF animals

Seven proteins involved in structural cellular integrity were found to be differentially expressed in our study. Thereof, five (annexin A2, moesin, gelsolin isoform 1, cytokeratin 
8, and microfibril-associated glycoprotein 4) were down-regulated and two (beta-actin, tubulin alpha-1C chain) were up-regulated in heart failure. Importantly, since only proteins from specific cellular components were underexpressed, this might rather reflect a true loss of cellular protein content than a mere reduction of cell quantity. Accordingly, the downregulation of mainly cytoarchitectural proteins indicates a profound disturbance of structural cell integrity.

Annexin A2, which was detected especially in the subepithelial layer and basement membranes in our study, is supposed to crosslink plasma membrane domains with the actin polymerization apparatus [33] and hence seems to play an important role in reorganization of the cytoskeleton and cell adhesion. Interestingly, annexin A 2 was also found to mediate membrane fusion of surfactant factor containing lamellar bodies in alveolar epithelial type II cells [34-37], which means that a downregulation of this protein would also hamper the exocytotic release of the surfactant factor. Moesin, which was highly expressed in the interalveolar septa and downregulated in heart failure, is another protein crosslinking the actin cytoskeleton and the plasma membrane. This protein belongs to the ezrin/radixin/ moesin (ERM) protein family and has been shown to be critical for preserving alveolar architecture and lung homeostasis [38]. Furthermore, the ERM protein complex is intricately involved in the modulation of endothelial permeability [39]. This was shown in two studies from Adyshev`s working group, where a depletion of moesin using a siRNA approach resulted in an attenuation of a thrombin-induced increase of endothelial cell barrier function [40] and in a further rise of angiogenic sphingolipid S1P-induced endothelial barrier enhancement [41]. By extrapolating these results, the downregulation of moesin in our study might either be indicative for a disturbed cytoarchitecture or could be interpreted as compensatory mechanism to enhance the otherwise impaired endothelial barrier function. The latter seems plausible in the context of the also downregulated protein gelsolin: this protein has likewise been shown to play a role in modulating endothelial barrier function. But contrary to moesin, in this case a deficiency of the protein was found to cause an increase of pulmonary vascular permeability [42], which could probably be counteracted by the downregulation of moesin.

Cytokeratin 8 belongs to the intermediate filament network, and its pulmonary underexpression in heart failure seems to be stress-responsive, as it has been evidenced before $[43,44]$. Also microfibril-associated glycoprotein 4 was downregulated in our study. Even though this extracellular matrix protein has already been described to colocalize with surfactant protein A (SP-A) in the interalveolar septum and in the elastic lamina of pulmonary arteries [45], its molecular function remains elusive.

Whereas all these cytoarchitectural proteins were downregulated in heart failure, two proteins (i.e., beta-actin and tubulin alpha-1C chain) were overexpressed: tubulin alpha-1cexpression has already been described to be increased in endothelial and -to a lesser extent - in epithelial cells due to a rise of interstitial lung pressure [46], so the upregulation of this protein largely seems to be stress-responsive. Also, beta-actin has been described to play an important role in stress response: Ito et al. found that mechanical stretch acting on pulmonary tissue activates cellular calcium influx, which is tightly regulated by the actin cytoskeleton [47], and Kerem et al. in their heart failure model described a strong increase of beta-actin in pulmonary endothelial cells, leading to an impaired endothelial calcium homeostasis and endothelial dysfunction [48].

Pulmonary anti-oxidative capacity is impaired in tachycardia-induced heart failure

Three pulmonary proteins involved in anti-oxidative processes were downregulated in our study: Catalase, which has been detected in two different localizations on the twodimensional gels most probably due to protein modifications, is a major pulmonary enzymatic antioxidant [49] with an already proposed therapeutic potential [50]. Biliverdin reductase catalyzes the reduction of biliverdin to bilirubin, which in turn has been proved to be a major antioxidant cytoprotectant being able to protect cells from a 10,000 fold excess of $\mathrm{H}_{2} \mathrm{O}_{2}$ [51]. Furthermore, this enzyme participates in an amplification cycle, where bilirubin is itself oxidized to biliverdin and afterwards reconverted by biliverdin reductase 
[51]. Thus, a downregulation of this protein would disturb this cycle, reduce the amount of generated bilirubin, and therefore impair the antioxidative capacity of this system. Finally, mitochondrial aldehyde dehydrogenase 2 was underexpressed in in our study. This enzyme was evidenced to protect from oxidative stress [52] by reducing ROS, which results in an attenuation of hyperoxia-induced cell death of pulmonary epithelial cells [53]. As above, a downregulation of this protein would likewise impair the antioxidative capacity.

Most interestingly, an oxidant/antioxidant imbalance as it is caused by a downregulation of antioxidative enzymes, has been shown to act as profibrotic stimulus leading to pulmonary fibrosis $[49,54]$. Against this background it would be intriguing to speculate that an impairment of the pulmonary antioxidative potential, as it has been seen in our study, would be the starting point for the later maladaptive profibrotic remodeling of lungs in heart failure.

\section{Heart failure provokes an altered pulmonary selenium metabolismus}

Two different proteins participating in the metabolismus of selenium compounds were differentially expressed in our study: Indolethylamine $N$-methyltransferase, which was upregulated in heart failure, and selenium binding protein 1, which was identified in two spatially different spots of the two-dimensional gels (with one being up- and one being downregulated). The latter expression behaviour might most probably be attributable to a different regulation of two out of three described isoforms of selenium binding protein 1 [55], whose molecular function is unclear so far [56]. Despite an ongoing lack of knowledge about the detailed role of selenium metabolism, it has nevertheless been shown that lower selenium levels are associated with an increased risk of mortality and a worse immune function [57], so an alteration of selenium-metabolizing compounds as shown in our study could possibly be interpreted against this background.

\section{Plasma components in lung tissue indicate impaired alveolar-capillary permeability}

Numerous protein spots, each representing serum albumin, were found to be upregulated on the two-dimensional gels in heart failure animals. Furthermore, fibrinogen was identified in several protein spots, which were both up- and downregulated. This more complex expression behaviour is difficult to explain, but might possibly indicate a higher pulmonary fibrinogen turnover in heart failure. Since albumin was mainly detected in interalveolar septa in our study, these serum proteins are indicative for an impaired alveolar-capillary barrier function, as it has been described before [58].

\section{Limitations}

Since we intended to detect also unpredictable molecular alterations, we conceived an unbiased methodological approach using well established proteomic techniques. This in turn means that the true potential of our study (as of every classical proteomic work) rather lies in generating new hypotheses than in unveiling novel causalities. It is clearly reserved for future experiments to verifiy these hypotheses and to evaluate their functional relevance. These studies could also validate the cellular localizations of the differentially expressed proteins by applying sensitive cell isolation techniques (such as laser microdissection).

Furthermore, by choosing ph 3-10 IPG strips for our experiments, we analyzed a large, but nevertheless only one part of the pulmonary proteome. So we cannot claim to cover all differential protein expressions, which might also have occured both in the more basic and acidic regions.

\section{Integrative concept and conclusion}

Our study revealed a molecular fundament of pulmonary stress failure in experimental tachycardiomyopathy. By integrating our findings, we hypothesize that the profound molecular alterations of the cytoarchitecture would translate in an impaired structural integrity of the alveolar-capillary barrier (which has been ultrastructurally described as cellular disruptions by others), provoking an increase of alveolar-capillary permeability. 
Furthermore, a downregulation of antioxidative enzymes indicates an impaired ROSdeactivating capacity, which in turn could fuel the later profibrotic remodeling of lungs thereby initiating a circulus vitiosus, which ends - as in the heart - in a maladaptive functional deterioration of the organ. Finally, an altered selenium metabolism might influence immune response processes, even though its functional relevance remains vague in this context (see Fig. 5). Provided that future works will verify these hypotheses, our study presents potential molecular targets for therapeutic interventions in this clinically meaningful disease complex.

\section{Acknowledgement} Winkel.

The authors gratefully appreciate the outstanding technical assistance of Ms. Ingrid

\section{Conflicts of Interest}

All authors declare that they do not have any conflicts of interest.

\section{References}

$\checkmark 1$ Angermann CE: Comorbidities in heart failure: a key issue. Eur J Heart Fail 2009;8:i5-i10.

-2 Goldsmith SR, Brandimarte F, Gheorghiade M: Congestion as a therapeutic target in acute heart failure syndromes. Prog Cardiovasc Dis 2010;52:383-392.

-3 Monnet X, Teboul JL, Richard C: Cardiopulmonary interactions in patients with heart failure. Curr Opin Crit Care 2007;13:6-11.

4 Costello ML, Mathieu-Costello 0, West JB: Stress failure of alveolar epithelial cells studied by scanning electron microscopy. Am Rev Respir Dis 1992;145:1446-1455.

5 Guazzi M: Alveolar-capillary membrane dysfunction in chronic heart failure: pathophysiology and therapeutic implications. Clin Sci 2000;98:633-641.

-6 Tsukimoto K, Mathieu-Costello O, Prediletto R, Elliott AR, West JB: Ultrastructural appearances of pulmonary capillaries at high transmural pressures. J Appl Physiol 1991;71:573-582.

7 West JB: Invited review: pulmonary capillary stress failure. J Appl Physiol 2000;89:2483-2489; discussion 2497.

8 Guazzi M: Alveolar gas diffusion abnormalities in heart failure. J Card Fail 2008;14:695-702.

-9 Guazzi M: Alveolar-capillary membrane dysfunction in heart failure: evidence of a pathophysiologic role. Chest 2003;124:1090-1102.

10 Huang W, Kingsbury MP, Turner MA, Donnelly JL, Flores NA, Sheridan DJ: Capillary filtration is reduced in lungs adapted to chronic heart failure: morphological and haemodynamic correlates. Cardiovasc Res 2001;49:207-217.

-11 Lee YS: Electron microscopic studies on the alveolar-capillary barrier in the patients of chronic pulmonary edema. Jpn Circ J 1979;43:945-954.

$>12$ Kingsbury MP, Huang W, Donnelly JL, Jackson E, Needham E, Turner MA, Sheridan DJ: Structural remodelling of lungs in chronic heart failure. Basic Res Cardiol 2003;98:295-303.

13 Birner C, Dietl A, Deutzmann R, Schröder J, Schmid P, Jungbauer C, Resch M, Endemann D, Stark K, Riegger G, Luchner A: Proteomic profiling implies mitochondrial dysfunction in tachycardia-induced heart failure. J Card Fail 2012;18:660-673.

14 Birner C, Husser O, Jeron A, Rihm M, Fredersdorf S, Resch M, Schmid P, Endemann D, Riegger G, Luchner A: Differential expression of potassium channels and abnormal conduction in experimental tachycardiainduced heart failure. Naunyn Schmiedebergs Arch Pharmacol 2012;385:473-480.

15 Birner C, Ulucan C, Bratfisch M, Götz T, Dietl A, Schweda F, Riegger GA, Luchner A: Antihypertrophic effects of combined inhibition of the renin-angiotensin system (RAS) and neutral endopeptidase (NEP) in progressive, tachycardia-induced experimental heart failure. Naunyn Schmiedebergs Arch Pharmacol 2012;385:1117-1125. 
Birner et al.: Lung Alterations in Heart Failure

16 Birner CM, Ulucan C, Fredersdorf S, Rihm M, Löwel H, Stritzke J, Schunkert H, Hengstenberg C, Holmer S, Riegger G, Luchner A: Head-to-head comparison of BNP and IL-6 as markers of clinical and experimental heart failure: Superiority of BNP. Cytokine 2007;40:89-97.

17 Luchner A, Muders F, Dietl O, Friedrich E, Blumberg F, Protter AA, Riegger GA, Elsner D: Differential expression of cardiac ANP and BNP in a rabbit model of progressive left ventricular dysfunction. Cardiovasc Res 2001;51:601-607.

18 Armstrong PW, Stopps TP, Ford SE, de Bold AJ: Rapid ventricular pacing in the dog: pathophysiologic studies of heart failure. Circulation 1986;74:1075-1084.

-19 Pak PH, Nuss HB, Tunin RS, Kääb S, Tomaselli GF, Marban E, Kass DA: Repolarization abnormalities, arrhythmia and sudden death in canine tachycardia-induced cardiomyopathy. J Am Coll Cardiol 1997;30:576-584.

20 Kamaruzaman NA, Kardia E, Kamaldin N', Latahir AZ, Yahaya BH: The rabbit as a model for studying lung disease and stem cell therapy. Biomed Res Int 2013;2013:691830.

21 Görg A, Weiss W, Dunn MJ: Current two-dimensional electrophoresis technology for proteomics. Proteomics 2004;4:3665-3685.

22 Görg A, Obermaier C, Boguth G, Harder A, Scheibe B, Wildgruber R, Weiss W: The current state of twodimensional electrophoresis with immobilized pH gradients. Electrophoresis 2000;21:1037-1053.

23 Yanagisawa K, Shyr Y, Xu BJ, Massion PP, Larsen PH, White BC, Roberts JR, Edgerton M, Gonzalez A, Nadaf S, Moore JH, Caprioli RM, Carbone DP: Proteomic patterns of tumour subsets in non-small-cell lung cancer. Lancet 2003;362:433-439.

24 Chen G, Gharib TG, Huang C, Thomas DG, Shedden KA, Taylor JMG, Kardia SLR, Misek DE, Giordano TJ, Iannettoni MD, Orringer MB, Hanash SM, Beer DG: Proteomic analysis of lung adenocarcinoma: identification of a highly expressed set of proteins in tumors. Clin Cancer Res 2002;8:2298-2305.

-25 Chang DW, Hayashi S, Gharib SA, Vaisar T, King ST, Tsuchiya M, Ruzinski JT, Park DR, Matute-Bello G, Wurfel MM, Bumgarner R, Heinecke JW, Martin TR: Proteomic and computational analysis of bronchoalveolar proteins during the course of the acute respiratory distress syndrome. Am J Respir Crit Care Med 2008;178:701-709.

-26 Houtman R, Krijgsveld J, Kool M, Romijn EP, Redegeld FA, Nijkamp FP, Heck AJ, Humphery-Smith I: Lung proteome alterations in a mouse model for nonallergic asthma. Proteomics 2003;3:2008-2018.

27 Zhang Y, Chen X, Hu Y, Du S, Shen L, He Y, Zhang Y, Zhang X, Li H, Yung RC: Preliminary characterizations of a serum biomarker for sarcoidosis by comparative proteomic approach with tandem-mass spectrometry in ethnic Han Chinese patients. Respir Res 2013;14:18.

28 Gevaert K, van Damme P, Martens L, Vandekerckhove J: Diagonal reverse-phase chromatography applications in peptide-centric proteomics: ahead of catalogue-omics? Anal Biochem 2005;345:18-29.

29 Townsley MI, Fu Z, Mathieu-Costello O, West JB: Pulmonary microvascular permeability. Responses to high vascular pressure after induction of pacing-induced heart failure in dogs. Circ Res 1995;77:317-325.

-30 Townsley MI, Snell KS, Ivey CL, Culberson DE, Liu DC, Reed RK, Mathieu-Costello O: Remodeling of lung interstitium but not resistance vessels in canine pacing-induced heart failure. J Appl Physiol 1999;87:1823-1830.

-31 Chen Y, Guo H, Xu D, Xu X, Wang H, Hu X, Lu Z, Kwak D, Xu Y, Gunther R, Huo Y, Weir EK: Left ventricular failure produces profound lung remodeling and pulmonary hypertension in mice: heart failure causes severe lung disease. Hypertension 2012;59:1170-1178.

32 West JB, Mathieu-Costello 0: Structure, strength, failure, and remodeling of the pulmonary blood-gas barrier. Annu Rev Physiol 1999;61:543-572.

33 Hayes MJ, Rescher U, Gerke V, Moss SE: Annexin-actin interactions. Traffic 2004;5:571-576.

-34 Chattopadhyay S, Sun P, Wang P, Abonyo B, Cross NL, Liu L: Fusion of lamellar body with plasma membrane is driven by the dual action of annexin II tetramer and arachidonic acid. J Biol Chem 2003;278:3967539683.

35 Chintagari NR, Jin N, Wang P, Narasaraju TA, Chen J, Liu L: Effect of cholesterol depletion on exocytosis of alveolar type II cells. Am J Respir Cell Mol Biol 2006;34:677-687.

36 Gou D, Mishra A, Weng T, Su L, Chintagari NR, Wang Z, Zhang H, Gao L, Wang P, Stricker HM, Liu L: Annexin A2 interactions with Rab14 in alveolar type II cells. J Biol Chem 2008;283:13156-13164.

-37 Singh TK, Abonyo B, Narasaraju TA, Liu L: Reorganization of cytoskeleton during surfactant secretion in lung type II cells: a role of annexin II. Cell Signal 2004;16:63-70. 
-38 Hashimoto S, Amaya F, Matsuyama H, Ueno H, Kikuchi S, Tanaka M, Watanabe Y, Ebina M, Ishizaka A, Tsukita S, Hashimoto S: Dysregulation of lung injury and repair in moesin-deficient mice treated with intratracheal bleomycin. Am J Physiol Lung Cell Mol Physiol 2008;295:L566-574.

39 Koss M, Pfeiffer GR, Wang Y, Thomas ST, Yerukhimovich M, Gaarde WA, Doerschuk CM, Wang Q: Ezrin/ radixin/moesin proteins are phosphorylated by TNF-alpha and modulate permeability increases in human pulmonary microvascular endothelial cells. J Immunol 2006;176:1218-1227.

-40 Adyshev DM, Dudek SM, Moldobaeva N, Kim K, Ma S, Kasa A, Garcia JGN, Verin AD: Ezrin/radixin/moesin proteins differentially regulate endothelial hyperpermeability after thrombin. Am J Physiol Lung Cell Mol Physiol 2013;305:L240-255.

41 Adyshev DM, Moldobaeva NK, Elangovan VR, Garcia JGN, Dudek SM: Differential involvement of ezrin/ radixin/moesin proteins in sphingosine 1-phosphate-induced human pulmonary endothelial cell barrier enhancement. Cell Signal 2011;23:2086-2096.

42 Becker PM, Kazi AA, Wadgaonkar R, Pearse DB, Kwiatkowski D, Garcia JGN: Pulmonary vascular permeability and ischemic injury in gelsolin-deficient mice. Am J Respir Cell Mol Biol 2003;28:478-484.

-43 Na N, Chandel NS, Litvan J, Ridge KM: Mitochondrial reactive oxygen species are required for hypoxiainduced degradation of keratin intermediate filaments. FASEB J 2010;24:799-809.

44 Ridge KM, Linz L, Flitney FW, Kuczmarski ER, Chou Y, Omary MB, Sznajder JI, Goldman RD: Keratin 8 phosphorylation by protein kinase $\mathrm{C}$ delta regulates shear stress-mediated disassembly of keratin intermediate filaments in alveolar epithelial cells. J Biol Chem 2005;280:30400-30405.

45 Schlosser A, Thomsen T, Shipley JM, Hein PW, Brasch F, Tornøe I, Nielsen O, Skjødt K, Palaniyar N, Steinhilber W, McCormack FX, Holmskov U: Microfibril-associated protein 4 binds to surfactant protein A (SP-A) and colocalizes with SP-A in the extracellular matrix of the lung. Scand J Immunol 2006;64:104116.

-46 Daffara R, Botto L, Beretta E, Conforti E, Faini A, Palestini P, Miserocchi G: Endothelial cells as early sensors of pulmonary interstitial edema. J Appl Physiol 2004;97:1575-1583.

47 Ito S, Suki B, Kume H, Numaguchi Y, Ishii M, Iwaki M, Kondo M, Naruse K, Hasegawa Y, Sokabe M: Actin cytoskeleton regulates stretch-activated $\mathrm{Ca} 2+$ influx in human pulmonary microvascular endothelial cells. Am J Respir Cell Mol Biol 2010;43:26-34.

48 Kerem A, Yin J, Kaestle SM, Hoffmann J, Schoene AM, Singh B, Kuppe H, Borst MM, Kuebler WM: Lung endothelial dysfunction in congestive heart failure: role of impaired $\mathrm{Ca}^{2+}$ signaling and cytoskeletal reorganization. Circ Res 2010;106:1103-1116.

49 Rahman I, Biswas SK, Kode A: Oxidant and antioxidant balance in the airways and airway diseases. Eur J Pharmacol 2006;533:222-239.

-50 Muzykantov VR: Delivery of antioxidant enzyme proteins to the lung. Antioxid Redox Signal 2001;3:39-62.

51 Baranano DE, Rao M, Ferris CD, Snyder SH: Biliverdin reductase: a major physiologic cytoprotectant. Proc Natl Acad Sci USA 2002;99:16093-16098.

52 Ohsawa I, Nishimaki K, Yasuda C, Kamino K, Ohta S: Deficiency in a mitochondrial aldehyde dehydrogenase increases vulnerability to oxidative stress in PC12 cells. J Neurochem 2003;84:1110-1117.

-53 Xu D, Guthrie JR, Mabry S, Sack TM, Truog WE: Mitochondrial aldehyde dehydrogenase attenuates hyperoxia-induced cell death through activation of ERK/MAPK and PI3K-Akt pathways in lung epithelial cells. Am J Physiol Lung Cell Mol Physiol 2006;291:L966-975.

54 Day BJ: Antioxidants as potential therapeutics for lung fibrosis. Antioxid Redox Signal 2008;10:355-370.

55 The UniProt Consortium: Update on activities at the Universal Protein Resource (UniProt) in 2013. http:// www.uniprot.org/uniprot/Q13228\#section_comments.

56 Behne D, Kyriakopoulos A: Mammalian selenium-containing proteins. Annu Rev Nutr 2001;21:453-473.

57 Rayman MP: Selenium and human health. Lancet 2012;379:1256-1268.

58 Bachofen H, Schürch S, Michel RP, Weibel ER: Experimental hydrostatic pulmonary edema in rabbit lungs. Morphology. Am Rev Respir Dis 1993;147:989-996. 